\title{
DIVERSITY OF ESCHERICHIA COLI RNA PHAGES
}

\section{ISOLATION AND CHARACTERIZATION OF NEW TYPE RNA PHAGES}

\author{
NOBUO TSUCHIDA, MEIHAN NONOYAMA \\ AND YONOSUKE IKEDA \\ The Institute of Applied Microbiology, University of Tokyo, \\ Bunkyo-ku, Tokyo, Japan
}

(Received September 29, 1970)

\begin{abstract}
Serological and chemical properties of the two RNA phages, designated $\mathrm{Y}$ and $\mathrm{Z}$, were investigated. Phage $\mathrm{Y}$ was serologically distinct from both phage $\beta$ closely related to MS2 and phage I distinct from $\beta$. From this observation, the presence of at least three types of RNA phages was suggested. Phage $Z$ was inactivated by antisera of I, Y, and $\beta$, and vice versa. $s_{20}$, w values of $\mathrm{Y}$ and $Z$ were estimated to be $82 \mathrm{~S}$ and $77 \mathrm{~S}$, respectively. The species specificities of these phages were discussed from the aspects of chemical composition of the RNA and the serological relationship.
\end{abstract}

According to ScotT (1) and Krueger (2), RNA phages MS2, f2, f4, and R17 isolated in U.S.A., fr and M12 isolated in Germany, and $\beta$ isolated at our laboratory in Tokyo are related to each other in their serological characters. On the other hand, isolation of RNA phages with different serological properties was reported by NONOYAMA et al. (3), WATANABE et al. (4-6), OVERBY et al. $(7,8)$, IKEDA et al. (9), and by OSAWA et al. (10). Among the RNA phages isolated by NoNOYAMA et al., phage I crossreacted with the anti- $\beta$-serum to the least degree and its RNA had a different base composition (11).

This paper deals with two RNA phages newly isolated. The serological and chemical properties were studied in comparison with those of phages $\beta$ and $\mathrm{I}$.

\section{MATERIALS AND METHODS}

Strain. As the host strain, Escherichia coli W2252 (Hfr Met $\left.^{-} \lambda^{-}\right)$was used. The nonlysogeny was checked by plating on $E$. coli $\mathrm{S}$.

RNA phages. $\quad \beta$ and I were used. Their properties have been described previously $(3,11)$.

Media. Bactotryptone medium (Difco bactotryptone $10 \mathrm{~g}$, Difco yeast 
extract $4 \mathrm{~g}, \mathrm{NaCl} 8 \mathrm{~g}$, glucose $1 \mathrm{~g}$, and $1,000 \mathrm{ml}$ water, $\mathrm{pH} \mathrm{7.0)}$ and an agar medium supplemented with $1.8 \%$ agar were used for growth and assay of phages. M-9' is an M-9 medium modified by supplementation with $500 \mu \mathrm{g} / \mathrm{ml}$ of casamino acid and $20 \mu \mathrm{g} / \mathrm{ml}$ of L-methionine. This M-9' medium was used for the one-step growth experiment. Bactopeptone medium (12) was used for ${ }^{32} \mathrm{P}$ incorporation experiment.

Isolation of RNA phages. As described previously (3), a small volume of sewage was plated with cells of strain W2252 onto the agar medium. When phages formed plaques, a portion of the plaque was, picked up by a needle and streaked on a new agar plate; the plate had been inoculated with W2252 and streaked with anti-I-serum. The two streaks were made at right angles to each other. After incubation at $37^{\circ}$ for $10 \mathrm{hr}$, the type of phages whose lytic activity was inhibited by the serum was selected. The selected phages were purified by the single plaque isolation and served for the determination of nucleic acids (3).

One-step growth experiment. E. coli cells $\left(2 \times 10^{8}\right.$ cells $\left./ \mathrm{ml}\right)$ grown in M$9^{\prime}$ medium were infected with phages at a multiplicity of 5 . Five minutes after infection, an anti-phage serum was added. The culture was diluted to $2 \times 10^{3} / \mathrm{ml}$ with a fresh medium after $10 \mathrm{~min}$. Aliquots were withdrawn at intervals during the cultivation at $37^{\circ}$ and plated with young cells of W2252.

Preparation of antiserum. Antisera were prepared as described by NONOYAMA et al. (3).

Serological cross-reaction test. Suspension of $10^{10}$ phages $/ \mathrm{ml}$ in saline $(0.8 \% \mathrm{NaCl})$ was mixed at $37^{\circ}$ with an equal volume of antiserum that had been diluted to appropriate concentrations. At intervals during the incubation aliquots were withdrawn, diluted to $10^{-4}$ with chilled saline, and plated. The rate constant, $k$ value, for inactivation of phage was calculated according to ADAms (13). The ratio of heterologous $k$ value to homologous $k$ value was defined as $\mathrm{K}^{\prime}$ as suggested by ScOTT (1).

Sedimentation velocity. Phage particles were purified as described previously (3) and dissolved in phosphate buffer $(0.05 \mathrm{M}, \mathrm{pH} 6.8)$. The solution containing various concentrations of phage particles was run in analytical ultracentrifuge (Hitachi UCA-1-type). Sedimentation coefficient ( $s_{20, w}$ value) of a phage was calculated according to the method of SCHACHMAN (14).

Preparation of ${ }^{32} \mathrm{P}$ phage $R N A$. E. coli cells $\left(10^{8}\right.$ cells $\left./ \mathrm{ml}\right)$ grown in bactopeptone medium were infected with phages at a multiplicity of 5 . Carrier-free ${ }^{32} \mathrm{P}(500 \mu \mathrm{Ci})$ was added to 5 -ml culture after 15 min of incubation and, after $35 \mathrm{~min}$, growth was stopped with $\mathrm{NaN}_{3}\left(10^{-2} \mathrm{M}\right.$, final concentration). The infected cells were converted to spheroplasts according to the method of GUTHRIE and SinSHEIMER (15). The spheroplasts were collected by low speed centrifugation and suspended in TM buffer (Tris buffer of $5 \times 10^{-3} \mathrm{M}$, $\mathrm{pH} 7.0$, supplemented with $\mathrm{MgCl}_{2}$ of $10^{-3} \mathrm{M}$ and $0.1 \mathrm{M} \mathrm{NaCl}$ ) containing deoxycholic acid $(0.2 \%)$ and $10 \mu \mathrm{g} / \mathrm{ml}$ of pancreatic DNase (Worthington Biochemical). After freezing and thawing of three times, the cell debris was. 


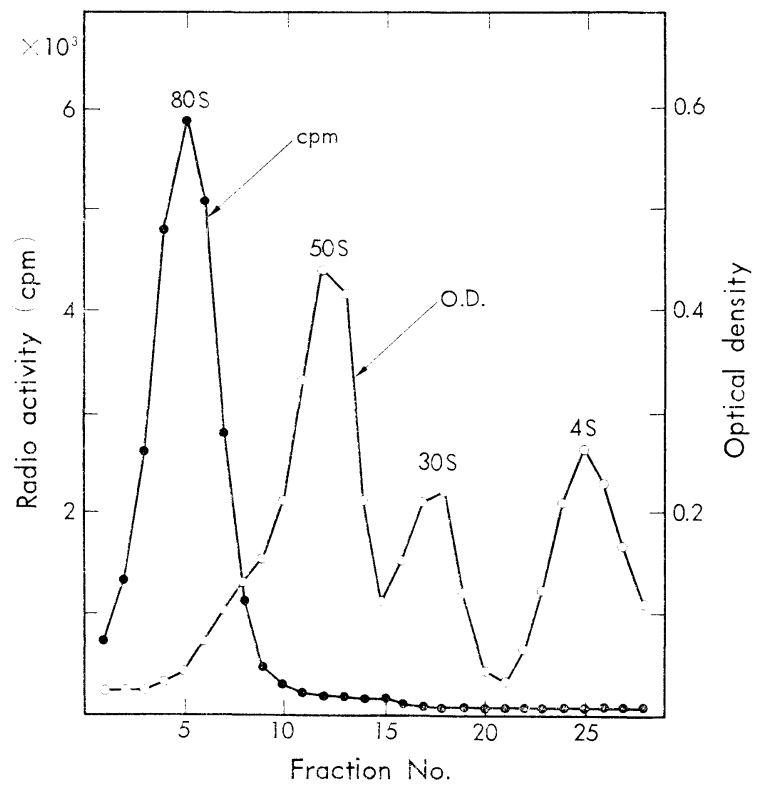

Fig. 1. Sucrose density gradient profile of purified ${ }^{32} \mathrm{P}$ phage $\mathrm{Y}$.

Optical density (E. coli sonicated lysate) - $-{ }^{3} \mathrm{P}$ Radioactivity (phage $\mathrm{Y}$ )

removed by centrifugation. The supernatant was dialyzed against TM buffer, and the undialyzable portion was fractionated by the sucrose density gradient centrifugation method (16), using a 5-20\% gradient of sucrose solution supplemented with TM buffer. The particles with the size of about $80 \mathrm{~S}$ were dialyzed against Tris buffer of $5 \times 10^{-3} \mathrm{M}(\mathrm{pH} 7.0)$ supplemented with $10^{-3} \mathrm{M}$ EDTA for $24 \mathrm{hr}$ (EDTA was added to accelerate the degradation of ribosomes), and then subjected to sucrose density gradient centrifugation again. The $80 \mathrm{~S}$ particles thus purified were considerably free from ribosomes and tRNA (Fig. 1). ${ }^{32} \mathrm{P}$-labeled phage RNA was prepared from the purified particles by the method described by NonOYAMA and IKEDA (12).

Base analysis. The ${ }^{32} \mathrm{P}$-phage RNA was dialysed against 1,000 volumes of distilled water and then hydrolysed with $\mathrm{KOH}(0.3 \mathrm{~N}$, final concentration) for $18 \mathrm{hr}$ at $37^{\circ}$. To minimize errors due to unequal loss of four nucleotides, cold RNA (2-3 mg, yeast RNA purchased from Nutritional Biochemical Corp.) was added to each sample prior to the hydrolysis. When the hydrolysis ended, the $\mathrm{pH}$ was adjusted to neutral with $\mathrm{HClO}_{4}$ and the appeared precipitate was removed by centrifugation. The supernatant was loaded on a Dowex$1 \times 2$ column and eluted with an exponential gradient of 0 to $4 \mathrm{~N}$ formic acid (12). Radioactivity of the eluates was measured in an automatic GM counter (Nippon Musen Co., Ltd.). 


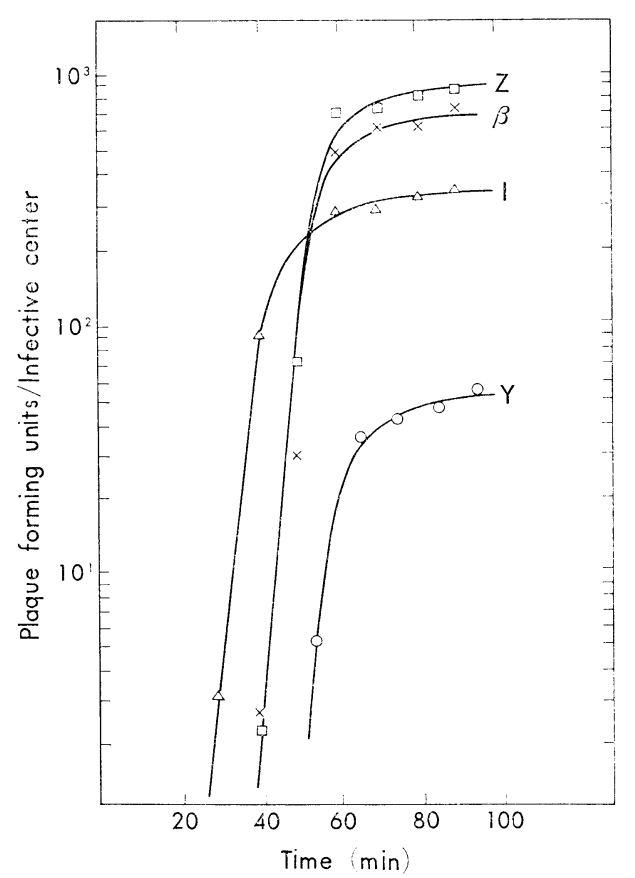

Fig. 2. Results of one-step growth experiments in $M-9^{\prime}$ medium.

\section{RESULTS}

\section{Isolation of phages $Y$ and $Z$}

NONOYAMA et al. (3) isolated several RNA phages from sewage in Tokyo by the method described in Materials and Methods using anti-MS2-serum. Among the phages isolated, phage $\beta$ was inactivated by the serum to the highest degree and phage I to the lowest degree. The isolation was attempted this time by using anti-I-serum in place of anti-MS2-serum. As a result, two phages, designated $\mathrm{Y}$ and $\mathrm{Z}$, were selected from 500 phages which attacked E. coli W2252. Both of the selected phages were demonstrated to be RNA phages and infected only male strains of $E$. coli.

\section{Plaque types and burst sizes}

Plaque types of the isolated phages were studied with purified phage stocks. When plated on bactotryptone medium and kept at $37^{\circ}$ for $10 \mathrm{hr}$, phage $\mathrm{Y}$ formed plaques that were significantly larger than those of $\mathrm{I}$. The plaques of phage $Z$ were turbid and smaller than those of phage $\beta$. The plaque types of phage $\beta$ and I have been presented in a previous paper (11).

Figure 2 shows results of one-step growth experiment. Phage Y showed a considerably longer latent period (about $50 \mathrm{~min}$ ) and significantly smaller 

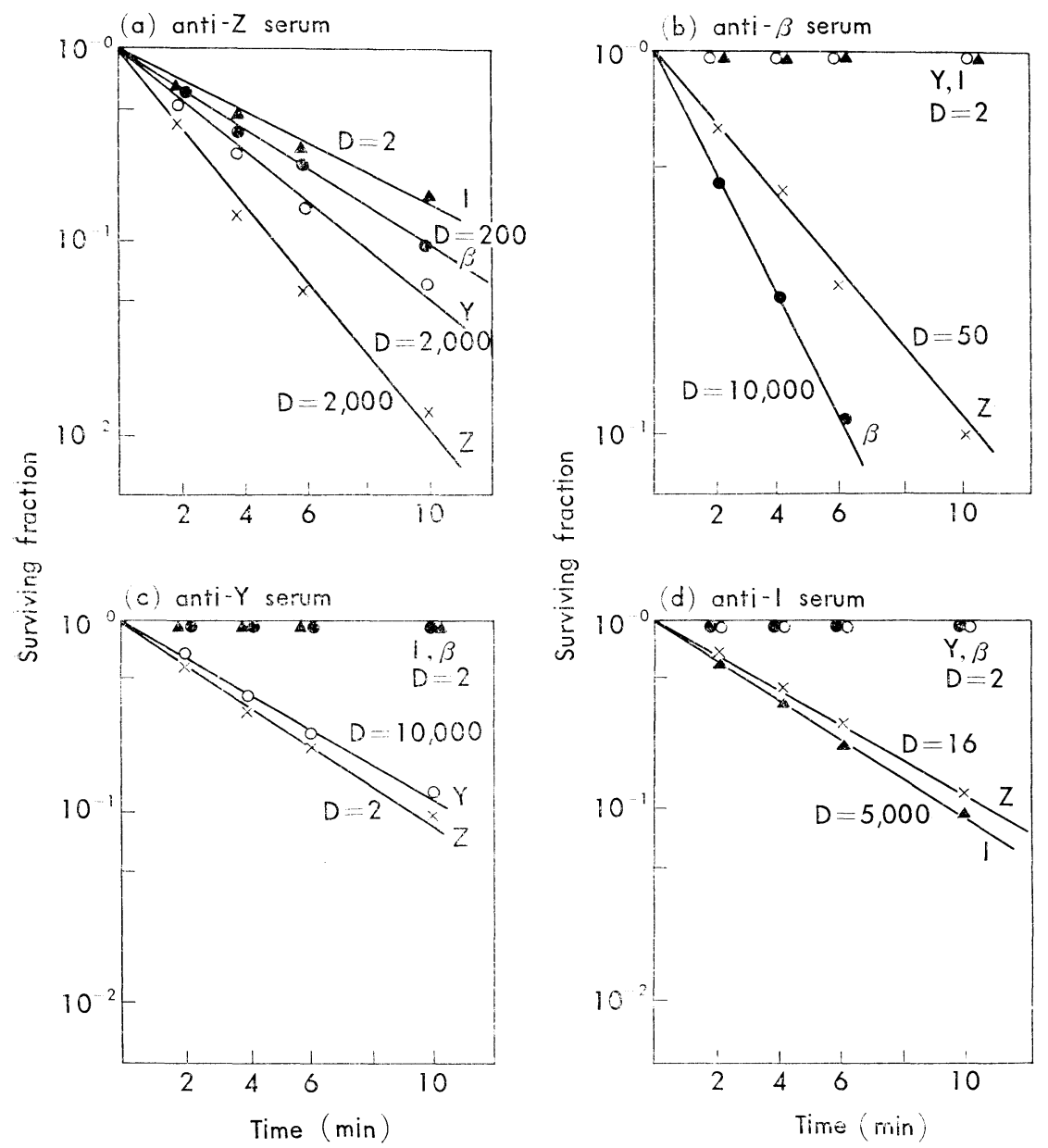

Fig. 3. Neutralization of RNA phages by antisera prepared against isologous and heterologous species.

$\mathrm{D}$ is the dilution rate of the used antiserum (Adams, 13).

burst size (about 50) than those of $\beta$ (40 min and 1,000 respectively). Phage $\mathrm{Z}$ produced results similar to those of phage $\beta$; the latent period was $40 \mathrm{~min}$ and the average burst size was 900 .

\section{Serological relationship}

Serological relationship of phage $\mathrm{Y}$ and $\mathrm{Z}$ to other phages was examined by the methods suggested by ADAMS (13) and by ScOTT (1). A mixture of a diluted serum and a phage was incubated at $37^{\circ}$ for $15 \mathrm{~min}$ and, at intervals during the incubation, a portion was withdrawn for titration. Fig. 3 shows 
Table $1 . \mathrm{K}^{\prime}$ and $k$ values of four RNA phages.

\begin{tabular}{c|c|c|c|c|c|}
\hline \multirow{2}{*}{ Antiserum } & $\begin{array}{c}k \text { values }^{a} \\
\left(\mathrm{~min}^{-1}\right)\end{array}$ & \multicolumn{4}{|c|}{$\mathrm{K}^{\prime}$ value $^{b}$} \\
\cline { 3 - 6 } & $\mathrm{Z}$ & $\mathrm{Y}$ & $\beta$ & $\mathrm{I}$ \\
\hline $\mathrm{Z}$ & $9.0 \times 10^{2}$ & 1 & 0.61 & 0.61 & $4.5 \times 10^{-3}$ \\
$\mathrm{Y}$ & $2.3 \times 10^{3}$ & $1.9 \times 10^{-4}$ & 1 & $<10^{-5}$ & $<10^{-5}$ \\
$\beta$ & $3.7 \times 10^{3}$ & $5.0 \times 10^{-2}$ & $<10^{-5}$ & 1 & $<10^{-5}$ \\
$\mathrm{I}$ & $1.1 \times 10^{3}$ & $2.8 \times 10^{-3}$ & $<10^{-5}$ & $<10^{-5}$ & 1 \\
\hline
\end{tabular}

a The rate constant for inactivation by homologous antiserum.

$b$ The ratio of heterologous $k$ value to homologous $k$ value.

Table 2. Base composition of some representative phage RNA's.

\begin{tabular}{|c|c|c|c|c|c|c|c|c|}
\hline \multirow{2}{*}{ Phage } & \multicolumn{8}{|c|}{ Base composition } \\
\hline & Uracil & Cytosine & Guanine & Adenine & $\mathrm{U} / \mathrm{A}$ & $\mathrm{C} / \mathrm{A}$ & $\mathrm{G} / \mathrm{A}$ & $\mathrm{GC} \%$ \\
\hline$\beta$ & $25.2 \pm 0.1^{a}$ & $24.7 \pm 0.7$ & $27.3 \pm 0.3$ & $22.8 \pm 0.4$ & 1.10 & 1.08 & 1.20 & 52.0 \\
\hline MS2 & $25.0 \pm 0.7$ & $25.3 \pm 0.7$ & $26.6 \pm 0.6$ & $23.1 \pm 0.7$ & 1.08 & 1.10 & 1.15 & 51.9 \\
\hline$Z$ & $26.5 \pm 0.6$ & $24.7 \pm 0.2$ & $27.3 \pm 0.5$ & $21.5 \pm 0.4$ & 1.23 & 1.15 & 1.27 & 52.0 \\
\hline $\mathrm{B}^{b}$ & 27.2 & 24.4 & 25.2 & 23.3 & 1.17 & 1.05 & 1.08 & 49.6 \\
\hline I & $27.8 \pm 0.1$ & $23.6 \pm 0.3$ & $25.7 \pm 0.4$ & $22.9 \pm 0.4$ & 1.21 & 1.03 & 1.11 & 49.3 \\
\hline $\mathrm{Y}$ & $29.4 \pm 0.5$ & $23.0 \pm 0.4$ & $25.7 \pm 0.5$ & $21.9 \pm 0.5$ & 1.34 & 1.05 & 1.17 & 48.7 \\
\hline $\mathrm{Q} \beta^{c}$ & 29.1 & 24.7 & 23.7 & 22.1 & 1.31 & 1.12 & 1.07 & 48.4 \\
\hline
\end{tabular}

a Mean of three independent analysis.

$b$ from reference (11).

$c$ from reference $(8)$.

results of neutralization experiments; a phage was neutralized with sera prepared against hemologous and heterologous phages. $k$ and $\mathrm{K}^{\prime}$ values were calculated from the neutralization curves and are shown in Table 1. These data suggest that (a) phages $Y, \beta$, and I are not serologically related to one another and (b) phage $Z$ is to some extent related to phages $\mathrm{Y}, \beta$, and $\mathrm{I}$. Under the employed conditions, the $\mathrm{K}^{\prime}$ value of $10^{-5}$, which was taken as the indication of unrelatedness, was the lowest limit of the assay.

Phage $\mathrm{Y}$ was isolated first as a phage which could be inactivated by anti-I-serum, but it was not inactivated in the above experiment. This variation might have occurred during the course of single plaque isolation.

\section{Sedimentation coefficients}

The values were found to be $82 \mathrm{~S}$ for $\mathrm{Y}$ and $77 \mathrm{~S}$ for $\mathrm{Z}$. 


\section{Base ratios}

Table 2 shows base ratios of five phage RNA's studied. The uracil content in Y-RNA was significantly higher than those in the remaining phage RNA's. The uracil content in Z-RNA was lower than that in Y-RNA and higher than that in $\beta$-RNA.

\section{DISCUSSION}

In DNA phages of $E$. coli, the base composition and serological character of the phages are taken as criteria for discriminating one phage type from another. In RNA phages, however, unusual bases such as 5-hydroxymethylcytosine have never been found. We wish to discuss, therefore, the species specificities of RNA phages from aspects of molar base ratio of the RNA and their serological relationship.

Table 2 shows the molar base ratios of five RNA phages isolated at our laboratory, as well as those of MS2 and Q $\beta$ (8). In RNA's of two serologically related phages, MS2 and $\beta$, the base ratios are almost equal, while in RNA's of phages $Q \beta$ and $Y$, that have been reported to be serologically distinct from MS2 and $\beta$ respectively, the U/A (uracil/adenine) ratio is considerably higher than that of $\beta$-MS2 group. The U/A ratio in phages B1, I, and $\mathrm{Z}$ is between that of $\mathrm{Y}-\mathrm{Q} \beta$ group and $\beta$-MS2 group. Moreover, the intermediate phages are serologically different from $\beta$ and $\mathrm{Y}(11$ and this paper). A similar conclusion is drawn even when the evaluation is made from the aspect of GC (guanine+cytosine) content. Because the observed differences in the base ratios are too large to consider them having been caused by a single or several events of mutation, we think that phages $\mathrm{Y}$, $Z, B 1$, and $I$ are distinct from phages MS2 and $\beta$ in their RNA structure. The results of annealing experiment reported in a previous paper (11) also support this view; the MS2 RNA formed a hybrid with the minus strand of $\beta$ RNA contained in the RNase-resistant RNA fraction in a yield of $95 \%$, but IRNA formed a hybrid with the minus strand in $20 \%$ yield.

We think that the serological character of a phage is an important criterion applicable for taxonomy, since a close correlation has been found between the serological character of a phage and the base composition of the phage RNA (11, and this paper). The phages isolated in our laboratory can be classified, serologically and chemically, into at least three groups ( $\beta, \mathrm{I}$, and $\mathrm{Y}$ groups). Recently, WATANABE and his colleagues $(5,6,10)$ proposed that $E$. coli RNA phages could be classified at least into three groups. Meanwhile, the present studies may not rule out the presence of intermediate groups. For example, phage $Z$ is sensitive to anti- $\beta$, anti-I, and anti- $Y$ sera. This phage may be an intermediate type. 


\section{REFERENCES}

1) D.W. ScotT, Virology, 26, 85 (1965).

2) R.G. KRUEGER, J. Virology, 4, 567 (1969).

3) M. Nonoyama, A. Yuki and Y. Ikeda, J. Gen. Appl. Microbiol., 9, 299 (1963).

4) I. Watanabe, Nippon Rinsho, 22, 243 (1964).

5) I. Watanabe, T. Miyake, T. Sakurai, T. Shiba and S. Ohno, Proc. Japan Acad., 43, 204 (1967).

6) I. Watanabe, T. Nishihara, H. Kaneko, T. Sakurai and S. Osawa, Proc. Japan Acad., 43, 210 (1967).

7) L.R. Overby, G.H. Barlow, R.H. Doi, M. Jacob and S. Spiegelman, J. Bacteriol., 91, 442 (1966).

8) L.R. Overby, G.H. Barlow, R.H. Doi, M. Jacob and S. Spiegelman, J. Bacteriol., 92, 739 (1966).

9) Y. Ikeda, A. Yuki, M. Nonoyama and N. TsuchidA, Abstr. Papers, IX Intern. Congr. Microbiol., 471 (1966), Moscow, USSR.

10) S. Osawa, T. Nishihara and I. Watanabe, Virus, 18, 1 (1967).

11) A. Yuki and Y. IkedA, J. Gen. Appl. Microbiol., 12, 763 (1966).

12) M. Nonoyama and Y. IkedA, J. Mol. Biol., 9, 763 (1964).

13) M.H. AdAms, Bacteriophages, Interscience Publishers Inc., New York (1959).

14) H.K. Schachman, Ultracentrifugation, diffusion and viscometry, Academic Press, Inc., New York (1957).

15) G.D. Guthrie and R.L. Sinsheimer, J. Mol. Biol., 2, 297 (1960).

16) N. Tsuchida, M. Nonoyama and Y. Ikeda, J. Mol. Biol., 20, 575 (1966). 